\title{
VOLUMETRIC AND VISCOMETRIC STUDIES ON ELECTROLYTES IN NON-AQUEOUS SOLVENT
}

\author{
M. A. Yousuf, K. M. Salim Reza, Md. Moniruzzaman, M. A. Aziz and ${ }^{1}$ M. A. Salam \\ Department of Chemistry \\ Khulna University of Engineering and Technology, Khulna, Bangladesh. \\ ${ }^{1}$ Department of Chemistry, University of Dhaka, Dhaka, Bangladesh. \\ E-mail: yousuf2716@yahoo.com
}

\begin{abstract}
The densities, $\rho$ and viscosities, $\eta$ of $\mathrm{NH}_{4} \mathrm{Cl}, \mathrm{NiCl}_{2}$ and $\mathrm{FeCl}_{3}$ in dimethylsulfoxide were studied as a function of concentration. The partial molal volume, $\left(\varphi_{v}^{0}\right)$ of these electrolytes were evaluated. The viscosity and viscosity-coefficients (A and $B$ ) were also determined by Jones-Dole equation. B-coefficient for $\mathrm{NiCl}_{2}$ and $\mathrm{FeCl}_{3}$ are positive that show structure making behavior in all the solutions while those of $\mathrm{NH}_{4} \mathrm{Cl}$ are negative indicating structure breaking properties. The coefficient A represents the solute-solute interactions coupled with size and shape effect of the solute and to some extent solute-solvent interactions. The behaviors of three solutes in binary systems were discussed in terms of the charge, size and hydrogen bonding effect.
\end{abstract}

Keywords: Density, Apparent and partial molal volume, viscosity coefficient.

\section{Introduction}

Volumetric and viscometric properties of binary mixtures have been very helpful to obtain information on the solute-solvent interactions and geometrical effects in the systems [1, 2]. Experimental results of viscosity measured in large concentration of electrolytes in aqueous solutions and the solvent-solvent interaction are available in the literature [3-10].

However, only limited numbers of experimental viscosity data of electrolytes in highly concentrated solution in non-aqueous solvents are available [11-12]. Solvent like, dimethylsulfoxide (DMSO) find a wide range of applications of technological importance, namely as solvent and solubilizing agents in organic synthesis, reaction kinetics and electrochemical studies [13-16]. A systematic study of the structural and energetic consequences of the interaction between electrolytes and DMSO will enable us to understand how electrolytes exercise thermodynamic and kinetic control over the chemical activities in non-aqueous media. On the basis of this hypothesis the title study has been undertaken.

\section{Experimental}

The reagents used were distilled DMSO, analytical grade chemicals viz., Ammonium Chloride (E-Merck, India), Nickel Chloride (EMerck, Germany) and Iron (III) Chloride (EMerck, Germany). DMSO was purified by a quick-fit glass made distillation apparatus and received at its boiling point, $189^{\circ} \mathrm{C}$. All the glass made apparatus were thoroughly cleaned and dried in electric oven. The smaller pieces of apparatus were dried in electric oven and stored in a desiccator, while larger pieces of apparatus were used directly from the oven. For viscosity measurement at different temperatures in range of $288 \mathrm{~K}$ to $313 \mathrm{~K}$, an Ostwald viscometer of British standard institution with a thermostat (The Fisher scientific TM 200) with fluctuation of $\pm 0.1^{\circ} \mathrm{C}$ was used. The flow of time was recorded by a timer accurate up to $\pm 0.01 \mathrm{~s}$. The densities of the solutions were determined by weighing a definite volume of the solution in a pycnometer at specified temperature. An electronic balance (HR-200, Made in Japan) with an accuracy of $\pm 0.0001 \mathrm{~g}$ was used for weighing.

\section{Results and Discussion}

The volumetric, viscometric and some other related properties of some inorganic salts such as $\mathrm{NH}_{4} \mathrm{Cl}, \mathrm{NiCl}_{2}$ and $\mathrm{FeCl}_{3}$ in a non-aqueous solvent, DMSO have been measured at the range of temperatures of 288, 293, 298, 303, 308 and $313 \mathrm{~K}$. The densities $\rho$ were tabulated in table-1 and the plots of density vs molality were shown in Fig. 1. The representative curves (Density vs molality) for all the electrolyte systems are almost linear in all solutions. The values of densities $\rho$ increase with the increasing molality of the electrolytes. 
Table 1 Densities $(\rho)$ of $\mathrm{NH}_{4} \mathrm{Cl}, \mathrm{NiCl}_{2}$ and $\mathrm{FeCl}_{3}$ in DMSO at $288 \mathrm{~K}, 293 \mathrm{~K}, 298 \mathrm{~K}, 303 \mathrm{~K}, 308 \mathrm{~K}$ and $313 \mathrm{~K}$ respectively

\begin{tabular}{|c|c|c|c|c|c|c|c|c|c|c|c|c|c|c|c|c|c|c|}
\hline $\begin{array}{c}\text { Concen- } \\
\text { tration } \\
\left(\mathrm{mol} \mathrm{kg}^{-1}\right)\end{array}$ & \multicolumn{3}{|c|}{$\mathbf{2 8 8} \mathbf{K}$} & \multicolumn{3}{|c|}{$\mathbf{2 9 3} \mathbf{K}$} & \multicolumn{3}{|c|}{$\mathbf{2 9 8} \mathbf{K}$} & \multicolumn{3}{|c|}{$\mathbf{3 0 3} \mathbf{K}$} & \multicolumn{3}{|c|}{$\mathbf{3 0 8 ~ K}$} \\
\hline 0.0402 & 1.1047 & 1.1095 & 1.1283 & 1.0995 & 1.1053 & 1.1232 & 1.0954 & 1.1002 & 1.1173 & 1.0899 & 1.0948 & 1.1123 & 1.0851 & 1.0900 & 1.1073 & 1.0797 & 1.0847 & 1.1022 \\
\hline 0.0806 & 1.1059 & 1.1161 & 1.1331 & 1.1004 & 1.1113 & 1.1283 & 1.0959 & 1.1064 & 1.1226 & 1.0906 & 1.1012 & 1.1186 & 1.0854 & 1.0951 & 1.1119 & 1.0803 & 1.0899 & 1.1068 \\
\hline 0.1212 & 1.1217 & 1.1204 & 1.1384 & 1.1016 & 1.1156 & 1.1333 & 1.0964 & 1.1112 & 1.1277 & 1.0912 & 1.1056 & 1.1222 & 1.0863 & 1.1001 & 1.1170 & 1.0809 & 1.0943 & 1.1113 \\
\hline 0.1619 & 1.1224 & 1.1248 & 1.1456 & 1.1190 & 1.1200 & 1.1388 & 1.1146 & 1.1159 & 1.1326 & 1.1095 & 1.1101 & 1.1265 & 1.1039 & 1.1050 & 1.1216 & 1.1004 & 1.0987 & 1.1155 \\
\hline 0.2439 & 1.1261 & 1.1343 & 1.1534 & 1.1209 & 1.1304 & 1.1482 & 1.1163 & 1.1255 & 1.1421 & 1.1111 & 1.1202 & 1.1364 & 1.1059 & 1.1152 & 1.1311 & 1.1017 & 1.1083 & 1.1254 \\
\hline 0.4101 & 1.1268 & 1.1566 & 1.1729 & 1.1230 & 1.1514 & 1.1680 & 1.1195 & 1.1459 & 1.1622 & 1.1139 & 1.1406 & 1.1555 & 1.1094 & 1.1356 & 1.1498 & 1.1044 & 1.1298 & 1.1434 \\
\hline
\end{tabular}

Table 2 Partial molal volume $\left(\varphi_{v}^{0}\right)$ of $\mathrm{NH}_{4} \mathrm{Cl}, \mathrm{NiCl}_{2}$ and $\mathrm{FeCl}_{3}$ in $\mathrm{DMSO}$ at $288 \mathrm{~K}, 293 \mathrm{~K}, 298 \mathrm{~K}, 303 \mathrm{~K}, 308 \mathrm{~K}$ and $313 \mathrm{~K}$ respectively

\begin{tabular}{|c|c|c|c|c|c|c|c|c|c|c|c|c|c|c|c|c|c|c|c|}
\hline \multirow{3}{*}{$\begin{array}{l}\text { Concentration } \\
\left(\mathrm{mol} \mathrm{kg}^{-1}\right)\end{array}$} & \multicolumn{19}{|c|}{ Partial Molal Volume } \\
\hline & \multicolumn{3}{|c|}{$288 \mathrm{~K}$} & \multicolumn{3}{|c|}{$293 \mathrm{~K}$} & \multicolumn{3}{|c|}{$298 \mathrm{~K}$} & \multicolumn{4}{|c|}{$303 \mathrm{~K}$} & \multicolumn{3}{|c|}{$308 \mathrm{~K}$} & \multicolumn{3}{|c|}{$313 \mathrm{~K}$} \\
\hline & $\begin{array}{l}\bar{U} \\
\bar{Z}\end{array}$ & $\underset{v}{\check{Z}}$ & 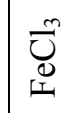 & $\begin{array}{l}\bar{U} \\
\bar{z} \\
\end{array}$ & 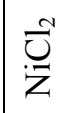 & $\underbrace{0}_{0}$ & $\begin{array}{l}\bar{U} \\
\overline{\mathbf{Z}} \\
\bar{Z}\end{array}$ & iृ & ن̃ & z & & $\underset{Z}{\Xi}$ & $\bigcup_{0}^{\infty}$ & $\begin{array}{l}\bar{J} \\
\text { 吉 } \\
\mathbf{Z}\end{array}$ & $\circlearrowright_{i}^{v}$ & $\underbrace{\infty}_{0}$ & $\begin{array}{l}\vec{J} \\
\bar{Z} \\
\bar{Z}\end{array}$ & $\stackrel{\circlearrowright}{\circlearrowright}$ & 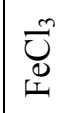 \\
\hline 0.0402 & \multirow{6}{*}{56} & \multirow{6}{*}{421} & \multirow{6}{*}{140} & \multirow{6}{*}{60} & \multirow{6}{*}{89} & \multirow{6}{*}{177} & \multirow{6}{*}{60} & \multirow{6}{*}{91} & \multirow{6}{*}{170} & \multirow{6}{*}{61} & \multirow{6}{*}{\multicolumn{2}{|c|}{90}} & \multirow{6}{*}{178} & \multirow{6}{*}{61} & \multirow{6}{*}{69} & \multirow{6}{*}{203} & \multirow{6}{*}{65} & \multirow{6}{*}{99} & \multirow{6}{*}{177} \\
\hline 0.0806 & & & & & & & & & & & & & & & & & & & \\
\hline 0.1212 & & & & & & & & & & & & & & & & & & & \\
\hline 0.1619 & & & & & & & & & & & & & & & & & & & \\
\hline 0.2439 & & & & & & & & & & & & & & & & & & & \\
\hline 0.4101 & & & & & & & & & & & & & & & & & & & \\
\hline
\end{tabular}

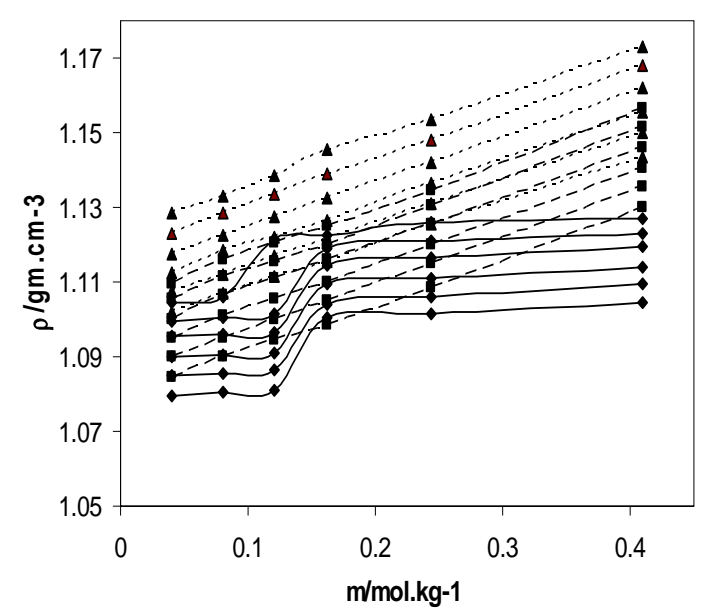

Fig. 1 Plots of Densities $(\rho)$ vs molality $(\mathrm{m})$ of $\mathrm{NH} 4 \mathrm{Cl}$ $(\bullet), \mathrm{NiCl} 2(\boldsymbol{\bullet})$ and $\mathrm{FeCl} 3(\boldsymbol{\Delta})$ in DMSO at $288 \mathrm{~K}, 293 \mathrm{~K}$, $298 \mathrm{~K}, 303 \mathrm{~K}, 308 \mathrm{~K}$ and $313 \mathrm{~K}$ respectively

The partial molal volume $\left(\varphi_{\mathrm{v}}{ }^{0}\right)$ of the solute (shown in table 2) slightly changes with the temperature. The $\varphi_{\mathrm{v}}{ }^{\mathrm{o}}$ values of the electrolytes reflect the true volume of the solute and the volume change arising from the solute-solvent interactions. The change in the $\varphi_{\mathrm{v}}{ }^{\mathrm{o}}$ of the electrolytes can be explained by considering of the charge and size of the cations and anions of the electrolytes. The salts $\mathrm{NH}_{4} \mathrm{Cl}, \mathrm{NiCl}_{2}$ and
$\mathrm{FeCl}_{3}$ contain mono-, di- and trivalent dissimilar cations having same anion.

The crystallographic radius of $\mathrm{NH}_{4}^{+}, \mathrm{Ni}^{2+}$ and $\mathrm{Fe}^{3+}$ are $1.43 \mathrm{~A}^{\circ}, \quad 0.72 \mathrm{~A}^{\circ}$ and $0.64 \mathrm{~A}^{\circ}$ respectively [17]. The variation of $\varphi_{v}{ }^{\circ}$ in these cases, therefore, may be due to the difference in ionic radii, charge density and ion-solvent interactions respectively. The variation of $\varphi_{v}{ }^{\circ}$ with molality of DMSO can be rationalized in terms of cosphere overlap model.

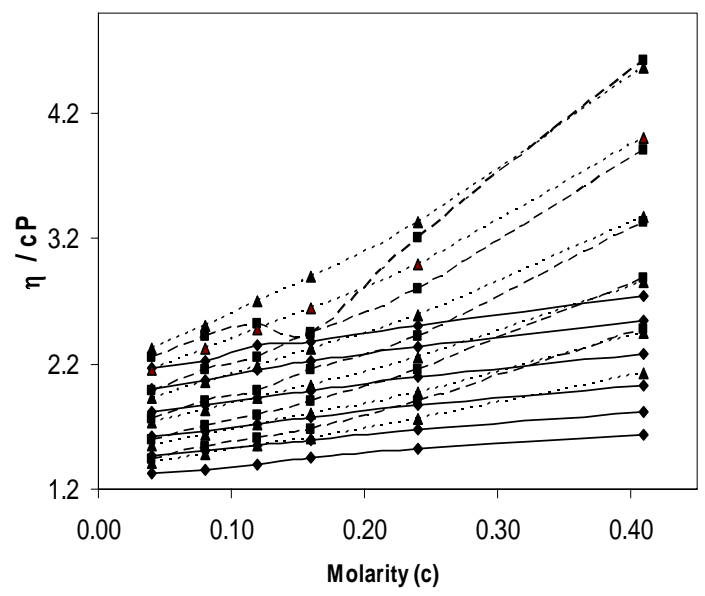

Fig. 2 Plots of Viscosities ( $\eta$ ) vs molarity (c) of $\mathrm{NH} 4 \mathrm{Cl}$ $(\bullet), \mathrm{NiCl} 2(\boldsymbol{\bullet})$ and $\mathrm{FeCl} 3(\boldsymbol{\Delta})$ in DMSO at $288 \mathrm{~K}, 293 \mathrm{~K}$, $298 \mathrm{~K}, 303 \mathrm{~K}, 308 \mathrm{~K}$ and $313 \mathrm{~K}$ respectively 
Table 3 Viscosities $(\eta)$ of $\mathrm{NH}_{4} \mathrm{Cl}, \mathrm{NiCl}_{2}$ and $\mathrm{FeCl}_{3}$ in DMSO at $288 \mathrm{~K}, 293 \mathrm{~K}, 298 \mathrm{~K}, 303 \mathrm{~K}, 308 \mathrm{~K}$ and $313 \mathrm{~K}$ respectively

\begin{tabular}{|c|c|c|c|c|c|c|c|c|c|c|c|c|c|c|c|c|c|c|}
\hline \multirow{2}{*}{$\begin{array}{l}\text { Concen- } \\
\text { tration } \\
\left(\mathrm{mol} \mathrm{kg}^{-1}\right)\end{array}$} & \multicolumn{3}{|c|}{$288 \mathrm{~K}$} & \multicolumn{3}{|c|}{$293 \mathrm{~K}$} & \multicolumn{3}{|c|}{$298 \mathrm{~K}$} & \multicolumn{3}{|c|}{$303 \mathrm{~K}$} & \multicolumn{3}{|c|}{$308 \mathrm{~K}$} & \multicolumn{3}{|c|}{$313 \mathrm{~K}$} \\
\hline & $\mathrm{NH}_{4} \mathrm{Cl}$ & $\mathrm{NiCl}_{2}$ & $\mathrm{FeCl}_{3}$ & $\mathrm{NH}_{4} \mathrm{Cl}$ & $\mathrm{NiCl}_{2}$ & $\mathrm{FeCl}_{3}$ & $\mathrm{NH}_{4} \mathrm{Cl}$ & $\mathrm{NiCl}_{2}$ & $\mathrm{FeCl}_{3}$ & $\mathrm{NH}_{4} \mathrm{Cl}$ & $\mathrm{NiCl}_{2}$ & $\mathrm{FeCl}_{3}$ & $\mathrm{NH}_{4} \mathrm{Cl}$ & $\mathrm{NiCl}_{2}$ & $\mathrm{FeCl}_{3}$ & $\mathrm{NH}_{4} \mathrm{Cl}$ & $\mathrm{NiCl}_{2}$ & $\mathrm{FeCl}_{3}$ \\
\hline 0.0402 & 2.1736 & 2.3696 & 2.3281 & 2.0012 & 2.2531 & 2.1588 & 1.8131 & 1.9886 & 1.9331 & 1.6155 & 1.7661 & 1.7309 & 1.4664 & 1.5935 & 1.5537 & 1.322 & 1.4439 & 1.416 \\
\hline 0.1212 & 2.3564 & 2.7356 & 2.6944 & 2.152 & 2.5179 & 2.4697 & 1.9287 & 2.2473 & 2.1799 & 1.7136 & 1.9888 & 1.9225 & 1.5472 & 1.784 & 1.717 & 1.3987 & 1.6089 & 1.5462 \\
\hline 0.1619 & 2.384 & 2.9668 & 2.9013 & 2.2186 & 2.4381 & 2.6421 & 1.9821 & 2.4537 & 2.3153 & 1.774 & 2.1526 & 2.0317 & 1.5982 & 1.8959 & 1.8084 & 1.4495 & 1.6816 & 1.6116 \\
\hline 0.4101 & 2.7484 & 5.2156 & 4.5718 & 2.5401 & 4.6243 & 3.9996 & 2.2804 & 3.907 & 3.3699 & 2.0276 & 3.3244 & 2.8482 & 1.8122 & 2.8827 & 2.4429 & 1.6391 & 2.4786 & 2.1212 \\
\hline
\end{tabular}

Table 4 Coefficients $\mathrm{A}$ and $\mathrm{B}$ of $\mathrm{NH}_{4} \mathrm{Cl}, \mathrm{NiCl}_{2}$ and $\mathrm{FeCl}_{3}$ in $\mathrm{DMSO}$ at $288 \mathrm{~K}, 293 \mathrm{~K}, 298 \mathrm{~K}, 303 \mathrm{~K}, 308 \mathrm{~K}$ and $313 \mathrm{~K}$ respectively

\begin{tabular}{|c|c|c|c|c|c|c|c|c|c|c|c|c|c|c|c|c|c|c|}
\hline \multirow[b]{2}{*}{$\begin{array}{c}\text { Concentration } \\
\left(\mathrm{mol} \mathrm{kg}^{-1}\right)\end{array}$} & \multicolumn{3}{|c|}{$288 \mathrm{~K}$} & \multicolumn{3}{|c|}{$293 \mathrm{~K}$} & \multicolumn{3}{|c|}{$298 \mathrm{~K}$} & \multicolumn{3}{|c|}{$303 \mathrm{~K}$} & \multicolumn{3}{|c|}{$308 \mathrm{~K}$} & \multicolumn{3}{|c|}{$313 \mathrm{~K}$} \\
\hline & $\begin{array}{l}\vec{U} \\
\vec{I} \\
\bar{Z}\end{array}$ & $\begin{array}{l}\vec{Z} \\
:\end{array}$ & 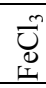 & $\begin{array}{l}\overrightarrow{U^{\prime}} \\
\mathbf{I}^{\prime}\end{array}$ & $\vec{Z}$ & రి & $\begin{array}{l}\vec{y} \\
\text { 艺 } \\
\end{array}$ & 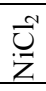 & $\underbrace{\infty}_{0}$ & $\begin{array}{l}\bar{U} \\
\vec{Z} \\
\vec{Z}\end{array}$ & $\underset{Z}{\stackrel{V}{Z}}$ & 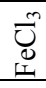 & $\begin{array}{l}\overrightarrow{U_{+}} \\
\overrightarrow{Z^{+}} \\
\end{array}$ & $\begin{array}{l}\vec{Z} \\
\dot{Z}\end{array}$ & ర্ঠ & $\begin{array}{l}\overrightarrow{y^{\prime}} \\
\text { 吾 }\end{array}$ & $\underset{Z}{\sim}$ & 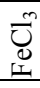 \\
\hline & \multicolumn{18}{|c|}{ A } \\
\hline $\begin{array}{l}0.0402 \\
0.0806 \\
0.1212 \\
0.1619 \\
0.2439 \\
0.4101 \\
\end{array}$ & \begin{tabular}{l}
+ \\
$\infty$ \\
$\infty$ \\
\multirow{N}{*}{} \\
$i n$
\end{tabular} & \begin{tabular}{l}
$\hat{\sigma}$ \\
\multirow{0}{0}{} \\
$\dot{\forall}$
\end{tabular} & $\begin{array}{l}\text { 三 } \\
\infty \\
\infty \\
\dot{\nabla}\end{array}$ & 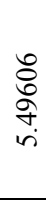 & $\begin{array}{l}0 \\
\stackrel{0}{n} \\
\text { ñ } \\
\text { in }\end{array}$ & 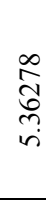 & 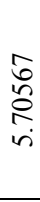 & 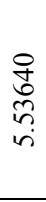 & 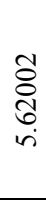 & 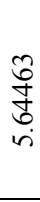 & $\begin{array}{l}\text { 于 } \\
\delta \\
0 \\
\dot{0}\end{array}$ & 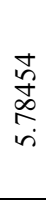 & $\frac{\hat{\sigma}}{\frac{\vec{V}}{\dot{r}}}$ & \begin{tabular}{l}
$\hat{b}$ \\
\multirow{2}{n}{} \\
in
\end{tabular} & $\begin{array}{l}\text { Dे } \\
\infty \\
\infty \\
\infty \\
\text { in }\end{array}$ & $\begin{array}{l}\mathbb{0} \\
\text { గ̂. } \\
i \\
i\end{array}$ & $\begin{array}{l}\underset{N}{\infty} \\
\underset{\infty}{\infty} \\
\text { in }\end{array}$ & $\begin{array}{l}0 \\
\text { ᄋ } \\
0 \\
0 \\
0 \\
0\end{array}$ \\
\hline & \multicolumn{18}{|c|}{ B } \\
\hline $\begin{array}{l}0.0402 \\
0.0806 \\
0.1212 \\
0.1619 \\
0.2439 \\
0.4101\end{array}$ & $\begin{array}{l}\stackrel{m}{+} \\
\stackrel{n}{n} \\
\stackrel{n}{r}\end{array}$ & $\begin{array}{l}8 \\
\infty \\
\infty \\
n \\
0\end{array}$ & 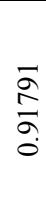 & 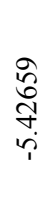 & 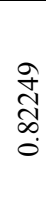 & $\begin{array}{l}\curvearrowleft \\
\check{n} \\
\text { aे }\end{array}$ & 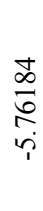 & $\begin{array}{l}\exists \\
\stackrel{\Xi}{\Xi} \\
\stackrel{n}{-}\end{array}$ & 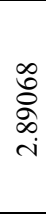 & \begin{tabular}{l}
\multirow{2}{R}{} \\
$\hat{\sigma}$ \\
$i$ \\
$i$
\end{tabular} & 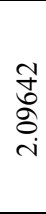 & $\begin{array}{l}\vec{N} \\
\underset{J}{\tilde{J}} \\
\dot{m}\end{array}$ & 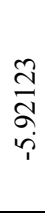 & $\begin{array}{l}n \\
\approx \\
\sigma \\
i \\
\sim\end{array}$ & 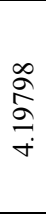 & 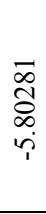 & 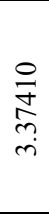 & $\frac{\substack{+\forall}}{\underset{+}{+}}$ \\
\hline
\end{tabular}

According to this model, the overlap of the cospheres of two similar ions or polar groups and an ion with that of a $=\mathrm{S}-\mathrm{O}$ group may produces positive volume change. On the other hand, the overlap of the cospheres of an ion with that of an aliphatic groups result in a negative change.

The viscosities and viscosity-coefficients (A and $\mathrm{B}$ ) of the chosen electrolytes were determined. The relevant data were shown in table-3 and 4. The representative curves (viscosity vs molarity) for all the electrolytes systems are linear in DMSO (shown in Fig-2). The values of $\eta$ increase with the increase in molarity of the electrolytes except $\mathrm{NH}_{4} \mathrm{Cl}$. Bcoefficient for electrolytes $\mathrm{NiCl}_{2}$ and $\mathrm{FeCl}_{3}$ in DMSO solutions at all the temperatures are positive while those of $\mathrm{NH}_{4} \mathrm{Cl}$ are negative. The positive $\mathrm{B}$ values of $\mathrm{NiCl}_{2}$ and $\mathrm{FeCl}_{3}$ correspond to the structure making behavior while $\mathrm{NH}_{4} \mathrm{Cl}$ exhibits structure breaking properties of them. Small and highly charged cations $\mathrm{Ni}^{2+}$ and $\mathrm{Fe}^{3+}$ strongly orient water molecules and in fact are believed to have a primary sheath of firmly attached molecules which moves with them as a kinetic entity and for these $\mathrm{Ni}^{2+}$ and $\mathrm{Fe}^{3+}$ ions show the fairly large and positive B-coefficient. On the other hand, the negative B-coefficient as well as the structure breaking tendency of $\mathrm{NH}_{4} \mathrm{Cl}$ can be explained by the consideration of large size and small charge density of $\mathrm{NH}_{4}{ }^{+}$ion.

The coefficient A represents the solute-solute interactions coupled with size and shape effect of the solute and to some extent solute-solvent interactions. In this study an irregular variation in values of A coefficient is found. This irregular variation in the values of $\mathrm{A}$ coefficient may be due to the incomplete dissociation and ion association of electrolyte in DMSO. The values of ' $A$ ' have been found to decrease with the rise of temperature. This is probably due to the greater thermal agitation and reduction of attractive forces between the ions. The increase in ' $A$ ' value can be explained by the inter-penetration effect, which brings the ions closer together. The higher positive $A$ values of $\mathrm{NiCl}_{2}$ and $\mathrm{FeCl}_{3}$ were observed. This is may be due to the higher charge to radius for $\mathrm{Ni}^{2+}$ and $\mathrm{Fe}^{3+}$. 


\section{Conclusion}

Volumetric and viscometric properties of some simple electrolytes e.g., $\mathrm{NH}_{4} \mathrm{Cl}, \mathrm{NiCl}_{2}$ and $\mathrm{FeCl}_{3}$ were studied in DMSO. Some interesting solution properties of these electrolytes were observed from these studies.

Both the volumetric and viscometric properties are depended upon electrolyte concentration as well as on the temperature. B-coefficient values for $\mathrm{NiCl}_{2}$ and $\mathrm{FeCl}_{3}$ in DMSO solutions are positive while those of $\mathrm{NH}_{4} \mathrm{Cl}$ are negative. $\mathrm{NiCl}_{2}$ and $\mathrm{FeCl}_{3}$ are more structured than $\mathrm{NH}_{4} \mathrm{Cl}$ in DMSO. This is probably due to the higher charge to radius ratio of $\mathrm{Ni}^{+2}$ and $\mathrm{Fe}^{3+}$ than that of $\mathrm{NH}_{4}^{+}$.

\section{Acknowledgement}

The authors acknowledge the Department of Chemistry, Khulna University of Engineering and Technology, for providing laboratory facilities of this work.

\section{References}

[1] T. M. Aminabhavi, K. Banerjee and R. H. Balundgi, Indian J. Chem., Vol. 38, Sect. A, 1999, pp. 768.

[2] B. Garcia, R. Alcalde, J. M. Leal and J. S. Matos, J. Phys. Chem. (B), Vol. 101, 1997, pp. 7991.
[3] T. M. Aminabhavi and S. S. Joshi, Indian J. Technol., Vol. 30, 1992, pp. 197.

[4] W. P. Jencks, "Catalysis in Chemistry and Enzymology" McGraw-Hill, New York, pp. 1969.

[5] E. A. Gomaa, Pro. Kon. Nedea. AK. Weten., Vol. 91B, 1988, pp. 363.

[6] M. Kato and N. Suzuki, J. Chem. Thermodyn., Vol. 10, 1978, pp. 435.

[7] S. Ottain, D. Vitalini, F. Comeli and C. Costellari, J. Chem. Eng. Data., Vol. 47, 2002, pp. 1197.

[8] A. Ali and A.K. Nain, Pramana J. Phys., Vol. 58, 2002, pp. 695.

[9] I. Gascom, H. Artigas, C. Lafunte, M. C. Lopez and f. M. Poyo, Fluid Phase Equilib., Vol. 202, 2002, pp. 385.

[10] Z. Wang, G. C. bensen and C.-Y. B. Lu, J. Chem. Thermodyn., Vol. 34, 2002, pp. 2037.

[11] P. S. Nikam, V. V. Patil and M. hasan, J. Indian Chem. Soc., Vol. 78, 2001, pp. 368.

[12] U. R. Kapadi, D. G. Hundiwale, N. B. patil, P. R. patil and M. K. Lande, J. Indian Chem. Soc., Vol. 77, 2000, pp. 319.

[13] P. J. Victor, P. K. Muhuri, B. Das and D. K. Hazra, J. Phys. Chem. (B), Vol. 104, 2000, pp. 5350.

[14] M. I. Aralaguppi, M. C. Jadav, T. M. Aminabhavi, J. D. Ortega and S. C. Mehrotra, J. Chem. Eng. Data, Vol. 42, 1997, pp. 301.

[15] P. S. Nikam, M. Hassan and R. B. pathak, J. Pur Appl. Ultrasonics, Vol. 18, 1996, pp. 19.

[16] D. Das, S. K. Roy and D. K. Hazra, J. Indian Chem. Soc., Vol. 80, 2003, pp. 385.

[17] R. D. Madan, "Modern Inorganic Chemistry" S. chand and company Ltd, New Delhi, 1990, pp1082, 1372. 